\title{
Recent Progress in the Genetics of Spontaneously Hypertensive Rats
}

\author{
M. PRAVENEC ${ }^{1}$, V. KŘEN ${ }^{1}$, V. LANDA ${ }^{1}$, P. MLEJNEK ${ }^{1}$, A. MUSILOVÁ ${ }^{1}$, J. ŠILHAVÝ ${ }^{1}$, \\ M. ŠIMÁKOVÁ ${ }^{1}$, V. ZÍDEK ${ }^{1}$
}

${ }^{1}$ Department of Genetics of Model Diseases, Institute of Physiology Academy of Sciences of the Czech Republic, Prague, Czech Republic

Received June 13, 2013

Accepted July 24, 2013

\begin{abstract}
Summary
The spontaneously hypertensive rat (SHR) is the most widely used animal model of essential hypertension and accompanying metabolic disturbances. Recent advances in sequencing of genomes of $\mathrm{BN}-\angle X$ and SHR progenitors of the $\mathrm{BXH} / \mathrm{HXB}$ recombinant inbred (RI) strains as well as accumulation of multiple data sets of intermediary phenotypes in the RI strains, including mRNA and microRNA abundance, quantitative metabolomics, proteomics, methylomics or histone modifications, will make it possible to systematically search for genetic variants involved in regulation of gene expression and in the etiology of complex pathophysiological traits. New advances in manipulation of the rat genome, including efficient transgenesis and gene targeting, will enable in vivo functional analyses of selected candidate genes to identify QTL at the molecular level or to provide insight into mechanisms whereby targeted genes affect pathophysiological traits in the SHR.
\end{abstract}

\section{Key words}

Spontaneously hypertensive rat • Recombinant inbred strains • Intermediary phenotypes • Transgenic • Gene targeting

\section{Corresponding author}

M. Pravenec, Institute of Physiology, Academy of Sciences of the Czech Republic, Vídeňská 1083, 14220 Prague 4, Czech Republic. Fax: (420)241062488. E-mail: pravenec@biomed.cas.cz

\section{Introduction}

Metabolic syndrome is a cluster of several risk factors for type 2 diabetes and cardiovascular disease, including obesity, hypertension, insulin resistance, and dyslipidemia. These pathological conditions are determined multifactorially by many genes and their interactions with environmental effects. Genome wide association studies (GWAS) in humans, which are based on the "common variants - common diseases" hypothesis, identified only a minor proportion of the total heritability of complex traits so far (Manolio et al. 2009). Statistically significant variants (SNPs - single nucleotide polymorphisms) are typically associated with a miniscule phenotypic variability without meaningful clinical effects, for instance, with less than $1 \mathrm{~mm} \mathrm{Hg}$ of blood pressure (Kurtz 2010). In addition, the associations of practically all significant variants with complex traits are based only on statistical evidence and most likely do not represent causal alleles, especially when they are often located within non-coding regions. Studies in animal models of human complex diseases can provide a useful alternative. Experiments with rat models can control for both genetic background and environmental effects as well as enable genetic manipulation of experimental animals. Although it cannot be expected that the individual predisposing genes themselves might be conserved between rats and humans, it is likely that the networks and pathways of genes leading to disease susceptibility will be conserved across species. Therefore, the identification of networks and pathways of genes underlying the cellular pathology of disease phenotypes in the rat could provide insight into the pathogenesis and treatment of the corresponding human diseases.

The spontaneously hypertensive rat (SHR) is the most widely used animal model of human essential hypertension and left ventricular hypertrophy and under 
special environmental conditions (for instance, when fed a high-fructose or folate-deficient diets) also develops disturbances of lipid and glucose metabolism that are typical for metabolic syndrome (Pravenec et al. 1999, 2013, Pravenec and Kurtz 2010). Similar to humans, these hemodynamic and metabolic disturbances in the SHR are also determined multifactorially. To identify genetic determinants of such complex traits, we used a combination of linkage and correlation analyses with intermediary phenotypes in the $\mathrm{BXH} / \mathrm{HXB}$ recombinant inbred (RI) strains and follow-up in vivo functional testing in SHR congenic and SHR transgenic or knockout lines.

\section{Intermediary phenotype data sets in the BXH/HXB recombinant inbred strains}

The BXH/HXB recombinant inbred (RI) strains were derived from reciprocal crosses between BN-Lx and SHR progenitors (Pravenec et al. 1989). For genetic dissection of complex pathophysiological traits in RI strains, it is possible to take the advantage of accumulated genotypes and intermediary phenotypes. Intermediate phenotypes have simpler genetic architectures and can be used for connecting variability at the DNA level with complex pathophysiological traits. For instance, the abundance of mRNA in tissues is a highly heritable trait (Petretto et al. 2006) and represents very useful intermediary phenotype since it is possible to identify cisand trans-regulated expression quantitative trait loci (eQTL) as candidate genes for complex traits. The most promising candidate genes are those that are (1) located close to the peak of QTL linkages of pathophysiological traits, (2) whose expression is regulated in cis, and (3) that correlate with the pathophysiological complex traits (Morrisey et al. 2011). The availability of genome sequences of both progenitor strains, the SHR and BN$L x$, enables rapid screening for functional variants of such candidate genes (Attanur et al. 2010, Simonis et al. 2012). We used this approach to identify the first QTL at the molecular level in the SHR, including mutant $O g n$ (osteoglycin) (Petretto et al. 2008) and Endog (endonuclease G) (McDermott-Roe et al. 2011) genes that predispose to left ventricular hypertrophy, deletion variant of $C d 36$ (fatty acid translocase) that is associated with metabolic disturbances and hypertension (Aitman et al. 1999, Pravenec et al. 2008) or Ebi2 (Epstein-Barr virus induced gene 2) gene that is associated with an inflammatory gene network and its human ortholog with predisposition to Type 1 diabetes (Heinig et al. 2010). Using similar approach, additional candidate genes have been identified, including genes associated with cardiac microvascular remodeling (Mancini et al. 2013), catecholamine sythesis and secretion (Jirout et al. 2010, Friese et al. 2013) or preference to alcohol (Tabakoff et al. 2009). In addition to cis-regulated eQTL, systemslevel approaches combining radiotelemetry blood pressures and transcriptome data revealed conservation of trans-regulated genes in the rat and genetic determinants of blood pressure in humans (Langley et al. 2013).

Additional intermediary phenotypes including quantitative proteomics determined by the SILAC (Stable isotope labeling by amino acids in cell culture) method (Nielsen et al., unpublished results), metabolomics (Le Ven et al. 2013), variability in microRNA abundance (Grunz et al. 2011), methylomics (Johnson et al. unpublished results), or histone modifications (Rintisch et al. 2011) are becoming available thanks to an international collaborative effort within the EURATRANS Integrated Project of the European Union (Abbott 2009). Analyses of these data sets will enable to identify networks of genes, transcripts, proteins, and metabolites that underlie pathophysiology of complex traits in the SHR.

\section{New technologies for derivation of genetically modified SHR lines}

Recently, new highly efficient techniques become available for derivation of transgenic or knockout rats for in vivo functional studies of candidate genes for QTL, for analyses of genes with unknown function or for derivation of new rat models of human diseases. These techniques include transposon-mediated transgenesis using microinjections of zygotes with mixes containing Sleeping Beauty constructs and mRNA of hyperactive SB100X transposase. The rate of transgenesis is $14-72 \%$ and in most cases only a single insertion outside coding regions is detected (Ivics et al. 2014, Katter et al. 2013). Until recently, gene targeting was impossible in the rat due to the absence of embryonic stem cells. Currently, several new techniques are available for gene targeting that are not based on the use of embryonic stem cells. These techniques include ZFN (Zinc finger nuclease) method (Jacob et al. 2010), TALEN (Transcription activator-like effector nuclease) method (Qiu et al. 2013) or CRISPR/Cas (Clustered regularly interspaced short palindromic repeats/(CRISPR-associated (Cas)) method 
(Wang et al. 2013). Recently, we derived multiple SHR trangenic lines using the Sleeping Beauty transposon constructs and mRNA of SB100X transposase, for instance lines expressing Venus, Nrf2, Dbh, Pnmt or Endog cDNA under the control of universal and tissuespecific promoters (Fig. 1A). In addition, we were able to obtain the first transgenic rat using the recombinasemediated cassette exchange (RMCE) method when green fluorescent protein Venus has been exchanged for red fluorescent protein Cherry in a defined position on chromosome 2 (Fig. 2) (Pravenec, Landa, Mátés, Izsvák, unpublished results). We have also derived SHR lines with disrupted Tmem70 gene using ZFN technology (Pravenec, Landa, Houštěk et al., unpublished results) or knockouted Plzf gene with the TALEN technique (Pravenec, Landa, Liška, Mátés, Izsvák, unpublished results) (Fig. 1B). Examples demonstrating usefulness of gene manipulation in the SHR for analysis of complex cardiometabolic traits are given below.
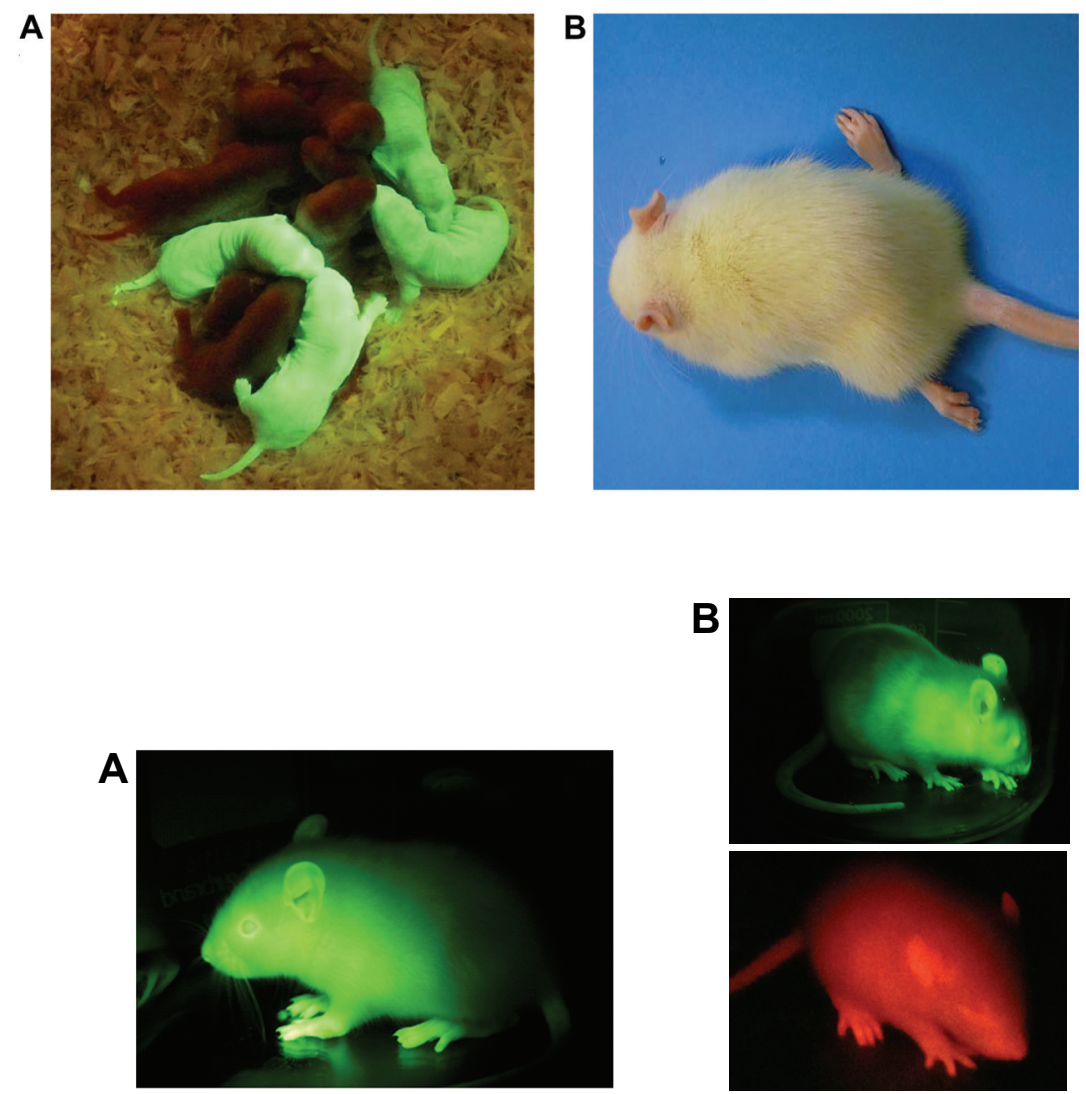

Chr2 acceptor locus homozygous recipient

\section{B}
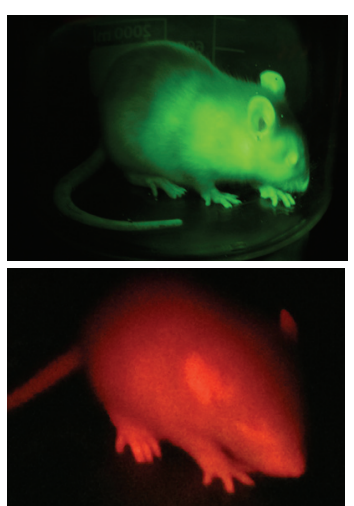

RMCE in the Chr2 acceptor locus

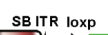

SBITR Ioxp Ioxp257 SB ITR

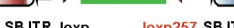
SBITR loxp
Fig. 1. Transposon-mediated transgenesis and TALEN method for gene targeting in the SHR. A. Two day old transgenic SHR rats with the Venus green fluorescent protein and their nontransgenic siblings. B. Plzf knockout SHR rat prepared by TALEN mediated mutagenesis with polydactyly.
Fig. 2. Transposon-coupled RMCE in pronuclear microinjection in the SHR. A. SHR homozygous line for the acceptor locus on chromosome 2. B. Successful single allele RMCE on chromosome 2 in SHR rat born from zygotes microinjected with a mix containing mCherry plasmid and Cre mRNA.

\section{Transgenic rescue experiments in the SHR}

To obtain definitive evidence for the identity of a candidate gene with a QTL that is associated with complex trait such as blood pressure, it is necessary to perform in vivo functional tests. For candidate genes with downregulated expression of mRNA or protein or with mutated nonfunctional protein, transgenic rescue experiments can provide such evidence. The SHR harbors a deletion mutation of the Cd36 gene that is associated with clustering of several cardiovascular risk factors, including predisposition to hypertension (Aitman et al. 1999, Pravenec et al. 1999, 2001). The mutated Cd36 protein is expressed, but its fatty acid translocase activity is significantly reduced (Hajri et al. 2001). In addition, renal expression of $\mathrm{Cd} 36$ is regulated in cis and genomewide quantitative trait transcript analysis in the BXH/HXB RI strains performed by searching for correlations between renal expression of cis-acting eQTLs and direct measurements of arterial pressure 
revealed that $C d 36$ showed the strongest correlation with diastolic blood pressure. The renal expression of $C d 36$ correlated inversely with blood pressure and RI strains with the SHR $C d 36$ allele had significantly higher blood pressure when compared to RI strains with the BN- $L x$ allele. To investigate whether mutant $C d 36$ in the kidney might be sufficient to promote increased blood pressure, we carried out renal transplantation experiments using donor kidneys from either the SHR progenitor that lacks wild-type $C d 36$ or from the SHR-TG19 transgenic strain with robust renal expression of wild-type $C d 36$. We found that blood pressure of recipients that received a donor kidney with mutant $C d 36$ was significantly greater than the blood pressure of recipients that received a "transgenic" kidney expressing wild-type $C d 36$ (Pravenec et al. 2008).

\section{"Humanized" SHR-CRP transgenic rats - a new model for testing the role of $\mathrm{C}$-reactive protein in the pathogenesis of metabolic syndrome}

Inflammation has been implicated in the pathogenesis of obesity, metabolic disturbances, diabetes mellitus, and cardiovascular disease. C-reactive protein (CRP) is a well-known biomarker of inflammation associated with increased risk for cardiovascular disease and diabetes. Whether or not CRP is a mediator or just a marker of disease pathogenesis remains highly controversial. The recent results from the JUPITER trial showed that statin therapy reduces cardiovascular risk more in patients who achieved substantial reductions in both CRP and LDL-cholesterol than in those who achieved substantial reductions in LDL-cholesterol without substantial reductions in CRP levels (Ridker et al. 2008). However, epidemiological studies and randomized trials of statins in relationship to CRP and coronary heart disease (CHD) cannot provide the evidence for causal relationship because of confounding effects of other risk factors for CHD and/or reverse causality. In addition, negative results in transgenic mice expressing human CRP did not also support a direct role of CRP in atherosclerosis development. However, it has been demonstrated that the mouse may not be a suitable genetic animal model for studying the biologic effects of human CRP. CRP is not an acute phase reactant in mice and human CRP fails to activate mouse complement in the presence of endogenous CRP ligands such as modified forms of cholesterol. Contrary to mice, human
CRP activates rat complement. Therefore we decided to test the effects of transgenic expression of human CRP in the SHR. The expression of human CRP specifically in the liver was associated with inflammation and oxidative tissue damage, insulin resistance and increased blood pressure (Pravenec et al. 2011a). These findings are consistent with the hypothesis that increased CRP is more than just a marker of inflammation and can directly promote multiple features of the metabolic syndrome. The humanized CRP transgenic SHR represents a new model for investigating mechanisms whereby increased CRP levels may promote multiple components of the metabolic syndrome and could be further used to search for genetic factors that might influence susceptibility to the adverse metabolic effects of human CRP. This transgenic SHR model should also be of interest for testing the therapeutic effects of statins or novel CRP inhibitors and a variety of other drugs such as antioxidants, anti-inflammatory agents, etc. Recently, we treated the SHR-CRP transgenic rats with rosuvastatin and observed significantly reduced inflammation and oxidative stress which was associated with amelioration of insulin resistance and dyslipidemia (Šilhavý et al. 2012). These findings provide support for the important pleiotropic effects of statins that are beyond LDL cholesterol lowering effects (Hayward et al. 2012).

\section{Autocrine effects of resistin in the pathogenesis of insulin resistance}

The adipokine resistin has been originally identified as a possible link between obesity and insulin resistance (Steppan et al. 2001). To analyze mechanisms of prodiabetic effects of resistin, we derived transgenic SHR expressing mouse resistin (Retn) cDNA under the control of aP2 promoter. Transgenic mouse resistin is expressed specifically in adipose tissue but is not secreted into circulation (Pravenec et al. 2003). Transgenic SHRRetn strain thus represents a unique model to analyze autocrine effects of resistin. SHR-Retn transgenic rats showed moderate expression of the resistin transgene in adipose tissue but had serum resistin levels similar to control SHR and undetectable levels of transgenic resistin in the circulation. Older transgenic rats displayed marked glucose intolerance in association with a near total resistance of adipose tissue to insulin-stimulated glucose incorporation into lipids. These results suggest that with increasing age, the autocrine effects of resistin in fat tissue may predispose to diabetes in part by impairing 
insulin action in adipose tissue (Pravenec et al. 2011b). Recently, brown adipose tissue (BAT) has been suggested to play an important role in the pathogenesis of metabolic disturbances by its ability to dissipate energy excess (Bartelt et al. 2011). Accordingly, we analyzed autocrine effects of transgenic resistin on BAT glucose and lipid metabolism in the SHR-Retn versus nontransgenic SHR controls. We observed that interscapular BAT isolated from SHR-Retn transgenic rats when compared to SHR controls showed lower relative weight, significantly reduced both basal and insulin-stimulated incorporation of palmitate into BAT lipids, and significantly decreased palmitate oxidation and glucose oxidation. These results provide compelling evidence that autocrine effects of resistin in BAT might play an important role in the pathogenesis of insulin resistance in the rat (unpublished results).

\section{Conclusions}

During several past years, major advances have been made in the genetic analysis of the SHR. The availability of genome sequences of BN-Lx and SHR progenitors of RI strains, the accumulation of genomewide intermediary phenotypes, as well as development of new statistical tools, enabled system-level approach for identification of genetic determinants of complex traits at the molecular level. In addition, recent advances in manipulation of the rat genome provide new tools for studying mechanisms whereby genes regulate complex pathophysiological traits.

\section{Conflict of Interest}

There is no conflict of interest.

\section{Acknowledgements}

This work was supported by grants LL1204 (within the ERC CZ program), LH12061, and LH11049 from the Ministry of Education, Youth and Sports of the Czech Republic, grants P303/10/0505, P301/10/0290, P301/12/0696, and 13-04420S from the Czech Science Foundation, grant NT/14325 from the Ministry of Health of the Czech Republic, and grant TA02010013 from the Technological Agency of the Czech Republic.

\section{References}

ABBOTT A: Return of the rat. Nature 460: 788, 2009.

AITMAN TJ, GLAZIER AM, WALLACE CA, COOPER LD, NORSWORTHY PJ, WAHID FN, AL-MAJALI KM, TREMBLING PM, MANN CJ, SHOULDERS CC, GRAF D, ST LEZIN E, KURTZ TW, KŘEN V, PRAVENEC M, IBRAHIMI A, ABUMRAD NA, STANTON LW, SCOTT J: Identification of Cd36 (Fat) as an insulin-resistance gene causing defective fatty acid and glucose metabolism in hypertensive rats. Nat Genet 21: 76-83, 1999.

ATANUR SS, BIROL I, GURYEV V, HIRST M, HUMMEL O, MORRISSEY C, BEHMOARAS J, FERNANDEZSUAREZ XM, JOHNSON MD, MCLAREN WM, PATONE G, PETRETTO E, PLESSY C, ROCKLAND KS, ROCKLAND C, SAAR K, ZHAO Y, CARNINCI P, FLICEK P, KURTZ T, CUPPEN E, PRAVENEC M, HÜBNER N, JONES SJ, BIRNEY E, AITMAN TJ: The genome sequence of the spontaneously hypertensive rat: Analysis and functional significance. Genome Res 20: 791-803, 2010.

BARTELT A, BRUNS OT, REIMER R, HOHENBERG H, ITTRICH H, PELDSCHUS K, KAUL MG, TROMSDORF UI, WELLER H, WAURISCH C, EYCHMÜLLER A, GORDTS PL, RINNINGER F, BRUEGELMANN K, FREUND B, NIELSEN P, MERKEL M, HEEREN J: Brown adipose tissue activity controls triglyceride clearance. Nat Med 17: 200-205, 2011.

FRIESE RS, ALTSHULER AE, ZHANG K, MIRAMONTES-GONZALEZ JP, HIGHTOWER CM, JIROUT ML, SALEM RM, GAYEN JR, MAHAPATRA NR, BISWAS N, CALE M, VAINGANKAR S, KIM H-S, COUREL M, TAUPENOT L, ZIEGLER MG, SCHORK NJ, PRAVENEC M, MAHATA SK, SCHMIDSCHÖNBEIN GW, O'CONNOR DT: MicroRNA22 and promoter motif polymorphisms at the Chga locus in genetic hypertension: functional and therapeutic implications for gene expression and the pathogenesis of hypertension. Hum Mol Genet 22: 3624-3640, 2013. 
GRUNZ KE, HEINIG M, VINGRON M, HUMMEL O, LINSEN SE, PRAVENEC M, CUPPEN E, HÜBNER N: Integrated miRNA expression profiling and linkage analysis for the identification of genetic variation underlying miRNA regulation in BXH/HXB RI strains. Rat Genetics \& Models, Cold Spring Harbor, 2011, p. 3.

HAJRI T, IBRAHIMI A, COBURN CT, KNAPP FF JR, KURTZ T, PRAVENEC M, ABUMRAD NA: Defective fatty acid uptake in the spontaneously hypertensive rat is a primary determinant of altered glucose metabolism, hyperinsulinemia, and myocardial hypertrophy. J Biol Chem 276: 23661-23666, 2001.

HAYWARD RA, KRUMHOLZ HM: Three reasons to abandon low-density lipoprotein targets. An open letter to the Adult Treatment Panel IV of the National Institutes of Health. Circ Cardiovasc Qual Outcomes 5: 2-5, 2012.

HEINIG M, PETRETTO E, WALLACE C, BOTTOLO L, ROTIVAL M, LU H, LI Y, SARWAR R, LANGLEY SR, BAUERFEIND A, HUMMEL O, LEE YA, PASKAS S, RINTISCH C, SAAR K, COOPER J, BUCHAN R, GRAY EE, CYSTER JG; CARDIOGENICS CONSORTIUM, ERDMANN J, HENGSTENBERG C, MAOUCHE S, OUWEHAND WH, RICE CM, SAMANI NJ, SCHUNKERT H, GOODALL AH, SCHULZ H, ROIDER HG, VINGRON M, BLANKENBERG S, MÜNZEL T, ZELLER T, SZYMCZAK S, ZIEGLER A, TIRET L, SMYTH DJ, PRAVENEC M, AITMAN TJ, CAMBIEN F, CLAYTON D, TODD JA, HÜBNER N, COOK SA: A trans-acting locus regulates an anti-viral expression network and type 1 diabetes risk. Nature 467: 460-464, 2010.

HÜBNER N, WALLACE CA, ZIMDAHL H, PETRETTO E, SCHULZ H, MACIVER F, MUELLER M, HUMMEL O, MONTI J, ZÍDEK V, MUSILOVÁ A, KŘEN V, CAUSTON H, GAME L, BORN G, SCHMIDT S, MÜlLER A, COOK SA, KURTZ TW, WHITTAKER J, PRAVENEC M, AITMAN TJ: Integrated transcriptional profiling and linkage analysis for identification of genes underlying disease. Nat Genet 37 : 243-253, 2005.

IVICS Z, MÁTÉS L, YAU TY, RÜLICKE T, BASHIR S, ZÍDEK V, LANDA V, PRAVENEC M, GEURTS A, HOFFMANN OI, HIRIPI L, BÖSZE Z, GARRELS W, KUES WA, IZSVÁK Z: Transposon-mediated germline transgenesis in rodents. Nat Protocol: 2014 (in press).

JACOB HJ, LAZAR J, DWINELL MR, MORENO C, GEURTS AM: Gene targeting in the rat: advances and opportunities. Trends Genet 26: 510-518, 2010.

JIROUT ML, FRIESE RS, MAHAPATRA NR, MAHATA M, TAUPENOT L, MAHATA SK, KŘEN V, ZÍDEK V, FISCHER J, MAATZ H, ZIEGLER MG, PRAVENEC M, HÜBNER N, AITMAN TJ, SCHORK NJ, O'CONNOR DT: Genetic regulation of catecholamine synthesis, storage and secretion in the spontaneously hypertensive rat. Hum Mol Genet 19: 2567-2580, 2010.

KATTER K, GEURTS AM, HOFFMANN O, MÁTÉS L, LANDA V, HIRIPI L, MORENO C, LAZAR J, BASHIR S, ZÍDEK V, POPOVA E, JERCHOW B, BECKER K, DEVARAJ A, WALTER I, GRZYBOWKSI M, CORBETT M, FILHO AR, HODGES MR, BADER M, IVICS Z, JACOB HJ, PRAVENEC M, BÖSZE Z, RÜLICKE T, IZSVÁK Z: Transposon-mediated transgenesis, transgenic rescue, and tissue-specific gene expression in rodents and rabbits. FASEB J 27: 930-941, 2013.

KURTZ TW: Genome-wide association studies will unlock the genetic basis of hypertension: con side of the argument. Hypertension 56: 1021-1025, 2010.

LANGLEY SR, BOTTOLO L, KUNEŠ J, ZICHA J, ZÍDEK V, HÜBNER N, COOK SA, PRAVENEC M, AITMAN TJ, PETRETTO E: Systems-level approaches reveal conservation of trans-regulated genes in the rat and genetic determinants of blood pressure in humans. Cardiovasc Res 97: 653-665, 2013.

LE VEN J, ROTIVAL M, PRAVENEC M, ZÍDEK V, NICHOLSON JK, PETRETTO E, DUMAS M-E: Mapping the genetic determinants of tissue metabotypes profiled by UPLC-MS in cardiometabolic diseases. 9th Annual Conference of the Metabolomics Society, Glasgow, 2013.

MANCINI M, PETRETTO E, KLEINERT C, SCAVONE A, DE T, COOK S, ŠILHAVÝ J, ZÍDEK V, PRAVENEC M, D'AMATI G, CAMICI PG: Mapping genetic determinants of coronary microvascular remodeling in the spontaneously hypertensive rat. Basic Res Cardiol 108: 316, 2013. 
MANOLIO TA, COLLINS FS, COX NJ, GOLDSTEIN DB, HINDORFF LA, HUNTER DJ, MCCARTHY MI, RAMOS EM, CARDON LR, CHAKRAVARTI A, CHO JH, GUTTMACHER AE, KONG A, KRUGLYAK L, MARDIS E, ROTIMI CN, SLATKIN M, VALLE D, WHITTEMORE AS, BOEHNKE M, CLARK AG, EICHLER EE, GIBSON G, HAINES JL, MACKAY TF, MCCARROLL SA, VISSCHER PM: Finding the missing heritability of complex diseases. Nature 461: 747-753, 2009.

MCDERMOTT-ROE C, YE J, AHMED R, SUN XM, SERAFÍN A, WARE J, BOTTOLO L, MUCKETT P, CAÑAS X, ZHANG J, ROWE GC, BUCHAN R, LU H, BRAITHWAITE A, MANCINI M, HAUTON D, MARTÍ R, GARCÍA-ARUMÍ E, HÜBNER N, JACOB H, SERIKAWA T, ZÍDEK V, PAPOUŠEK F, KOLÁŘ F, CARDONA M, RUIZ-MEANA M, GARCÍA-DORADO D, COMELLA JX, FELKIN LE, BARTON PJ, ARANY Z, PRAVENEC M, PETRETTO E, SANCHIS D, COOK SA: Endonuclease G is a novel determinant of cardiac hypertrophy and mitochondrial function. Nature 478: 114-118, 2011.

PETRETTO E, MANGION J, DICKENS NJ, COOK SA, KUMARAN MK, LU H, FISCHER J, MAATZ H, KŘEN V, PRAVENEC M, HÜBNER N, AITMAN TJ: Heritability and tissue specificity of expression quantitative trait loci. PLoS Genet 2: e172, 2006.

PETRETTO E, SARWAR R, GRIEVE I, LU H, KUMARAN MK, MUCKETT PJ, MANGION J, SCHROEN B, BENSON M, PUNJABI PP, PRASAD SK, PENNELL DJ, KIESEWETTER C, TASHEVA ES, CORPUZ LM, WEBB MD, CONRAD GW, KURTZ TW, KŘEN V, FISCHER J, HÜBNER N, PINTO YM, PRAVENEC M, AITMAN TJ, COOK SA: Integrated genomic approaches implicate osteoglycin (Ogn) in the regulation of left ventricular mass. Nat Genet 40: 546-552, 2008.

PRAVENEC M, KURTZ TW: Recent advances in genetics of the spontaneously hypertensive rat. Curr Hypertens Rep 12: 5-9, 2010.

PRAVENEC M, KLÍR P, KŘEN V, ZICHA J, KUNEŠ J: An analysis of spontaneous hypertension in spontaneously hypertensive rats by means of new recombinant inbred strains. J Hypertens 7: 217-221, 1989.

PRAVENEC M, ZÍDEK V, ŠIMÁKOVÁ M, KŘEN V, KŘENOVÁ D, HORKÝ K, JÁCHYMOVÁ M, MIKOVÁ B, KAZDOVÁ L, AITMAN TJ, CHURCHILL PC, WEBB RC, HINGARH NH, YANG Y, WANG JM, LEZIN EM, KURTZ TW: Genetics of $\mathrm{Cd} 36$ and the clustering of multiple cardiovascular risk factors in spontaneous hypertension. J Clin Invest 103: 1651-1657, 1999.

PRAVENEC M, LANDA V, ZÍDEK V, MUSILOVÁ A, KŘEN V, KAZDOVÁ L, AITMAN TJ, GLAZIER AM, IBRAHIMI A, ABUMRAD NA, QI N, WANG JM, ST LEZIN EM, KURTZ TW: Transgenic rescue of defective Cd36 ameliorates insulin resistance in spontaneously hypertensive rats. Nat Genet 27: 156-158, 2001.

PRAVENEC M, KAZDOVÁ L, LANDA V, ZÍDEK V, MLEJNEK P, JANSA P, WANG J, QI N, KURTZ TW: Transgenic and recombinant resistin impair skeletal muscle glucose metabolism in the spontaneously hypertensive rat. J Biol Chem 278: 45209-45215, 2003.

PRAVENEC M, CHURCHILL PC, CHURCHILL MC, VIKLICKÝ O, KAZDOVÁ L, AITMAN TJ, PETRETTO E, HÜBNER N, WALLACE CA, ZIMDAHL H, ZÍDEK V, LANDA V, DUNBAR J, BIDANI A, GRIFFIN K, QI N, MAXOVÁ M, KŘEN V, MLEJNEK P, WANG J, KURTZ TW: Identification of renal Cd36 as a determinant of blood pressure and risk for hypertension. Nat Genet 40: 952-954, 2008.

PRAVENEC M, KAJIYA T, ZÍDEK V, LANDA V, MLEJNEK P, ŠIMÁKOVÁ M, ŠILHAVÝ J, MALÍNSKÁ H, OLIYARNYK O, KAZDOVÁ L, FAN J, WANG J, KURTZ TW: Effects of human C-reactive protein on pathogenesis of features of the metabolic syndrome. Hypertension 57: 731-737, $2011 \mathrm{a}$.

PRAVENEC M, ZÍDEK V, LANDA V, ŠIMÁKOVÁ M, MLEJNEK P, ŠILHAVÝ J, MAXOVÁ M, KAZDOVÁ L, SEIDMAN JG, SEIDMAN CE, EMINAGA S, GORHAM J, WANG J, KURTZ TW: Age-related autocrine diabetogenic effects of transgenic resistin in spontaneously hypertensive rats: gene expression profile analysis. Physiol Genomics 43: 372-379, $2011 \mathrm{~b}$.

PRAVENEC M, KOŽICH V, KRIJT J, SOKOLOVÁ J, ZÍDEK V, LANDA V, ŠIMÁKOVÁ M, MLEJNEK P, ŠILHAVÝ J, OLIYARNYK O, KAZDOVÁ L, KURTZ TW: Folate deficiency is associated with oxidative stress, increased blood pressure, and insulin resistance in spontaneously hypertensive rats. Am J Hypertens 26: 135-140, 2013. 
QIU Z, LIU M, CHEN Z, SHAO Y, PAN H, WEI G, YU C, ZHANG L, LI X, WANG P, FAN HY, DU B, LIU B, LIU M, LI D: High-efficiency and heritable gene targeting in mouse by transcription activator-like effector nucleases. Nucleic Acids Res 41: e120, 2013.

RIDKER PM, DANIELSON E, FONSECA FA, GENEST J, GOTTO AM JR, KASTELEIN JJ, KOENIG W, LIBBY P, LORENZATTI AJ, MACFADYEN JG, NORDESTGAARD BG, SHEPHERD J, WILLERSON JT, GLYNN RJ; JUPITER STUDY GROUP: Rosuvastatin to prevent vascular events in men and women with elevated C-reactive protein. $N$ Engl J Med 359: 2195-2207, 2008.

RINTISCH C, HEINIG M, SCHÄFER S, PATONE G, COOK S, PRAVENEC M, VINGRON M, HÜBNER N: Quantitative genetic analysis of histone modifications in rat recombinant inbred strains. Rat Genetics \& Models, Cold Spring Harbor, 2011, p. 4.

ŠILHAVÝ J, ZÍDEK V, LANDA V, ŠIMÁKOVÁ M, MLEJNEK P, MAXOVÁ M, OLIYARNYK O, KAZDOVÁ L, SAAR K, SCHULZ H, HÜBNER N, KURTZ TW, PRAVENEC M: Pleiotropic effects of rosuvastatin on inflammation, oxidative stress, insulin resistance and target organ damage in CRP transgenic spontaneously hypertensive rats. FEBS $J \mathbf{2 7 9}$ (Suppl 1): 535, 2012.

SIMONIS M, ATANUR SS, LINSEN S, GURYEV V, RUZIUS FP, GAME L, LANSU N, DE BRUIJN E, VAN HEESCH S, JONES SJ, PRAVENEC M, AITMAN TJ, CUPPEN E: Genetic basis of transcriptome differences between the founder strains of the rat HXB/BXH recombinant inbred panel. Genome Biol 13: r31, 2012.

STEPPAN CM, BAILEY ST, BHAT S, BROWN EJ, BANERJEE RR, WRIGHT CM, PATEL HR: The hormone resistin links obesity to diabetes. Nature 409: 307-312, 2001.

TABAKOFF B, SABA L, PRINTZ M, FLODMAN P, HODGKINSON C, GOLDMAN D, KOOB G, RICHARDSON HN, KECHRIS K, BELL RL, HÜBNER N, HEINIG M, PRAVENEC M, MANGION J, LEGAULT L, DONGIER M, CONIGRAVE KM, WHITFIELD JB, SAUNDERS J, GRANT B, HOFFMAN PL; WHO/ISBRA STUDY ON STATE AND TRAIT MARKERS OF ALCOHOLISM: Genetical genomic determinants of alcohol consumption in rats and humans. BMC Biol 7: 70, 2009.

WANG H, YANG H, SHIVALILA CS, DAWLATY MM, CHENG AW, ZHANG F, JAENISCH R: One-step generation of mice carrying mutations in multiple genes by CRISPR/Cas-mediated genome engineering. Cell 153: 910-918, 2013. 